Short communication

\title{
Unusual lobed leaf development of the endemic medicinal plant Jatropha maheswarii Subr. \& Nayar (Euphorbiaceae)
}

\author{
V. Bharathy \\ Department of Botany, Fatima College (Autonomous), Madurai Kamaraj University, \\ Madurai, Tamil Nadu, India \\ *Corresponding Author: bharathystmarys@gmail.com \\ [Accepted: 12 December 2019] \\ [Cite as: Bharathy V (2019) Unusual lobed leaf development of the endemic medicinal plant Jatropha \\ maheswarii Subr.\& Nayar (Euphorbiaceae). Tropical Plant Research 6(3): 486-487]

\section{INTRODUCTION} \\ India is a tropical country with rich diversity of medicinal plant resources. In recent years study on the \\ medicinal plants has gained more momentum. The genus "Jatropha" of Euphorbiaceae is mainly focussed on \\ its biodiesel yielding property than its medicinal importance. Jatropha maheswarii Subr. \& Nayar is endemic to \\ the red clayey soils of southern east coastal regions of Thiruchendur, Tirunelveli and Kanyakumari districts of \\ Tamil Nadu and also in hilly regions of Thiruvananthapuram districts of Kerala (AbdulKader 2014). It is \\ commonly called as "Aadalai" (Ahmedullah \& Nayar 1986) or "Vel- adalai" by the local people. It is named \\ after Prof. Maheswarii (1904-1966), Indian botanist. It is an evergreen shrub which grows about 2.0-2.5 $\mathrm{m}$ in \\ height, drought-hardy and rhizomatous plant. This plant is used by the local people to treat skin diseases and to \\ stop haemorrhage (Sumathi \& Uthayakumari 2014). This plant used by the locals against rheumatism, \\ ringworms and as an insecticide (Viswanathan et al. 2004). Since this taxon is less explored it was selected for \\ the study.
}

\section{METHODS}

The study was done during the month of August and September 2017 in Thiruchendur, Tirunelveli and Kanyakumari districts and specimens were collected. During the time of collection, it was noted that the specimens seen near the village Kuttam in Tiruchendur district showed some unusual leaf character when compared to that of normal plants collected in other regions.

\section{RESULT \& DISCUSSSION}

Habit: The plant is a branched shrub with thick stem and underground rhizomatous roots (Ben \& Sivanadanam 2014).

Leaves: Leaves are dark green, alternate, simple, ovate to lanceolate, penninerved, with undulate margin, glaucous, veins intramarginal, petioles $3.5 \mathrm{~cm}$ long and glabrous (Uthayakumari \& Sumathi 2011, Ben \& Sivanadanam 2015). Elliptical and resembles mango leaves (Krishnan \& Paramathma 2009).

Inflorescence: Axillary, dichasial cyme, 5-10 cm long. Flowers: Unisexual, greenish yellow in colour. Fruits: Small capsule, round, ca. $3 \mathrm{~mm}$ and $1.5-2.0 \mathrm{~cm}$ long in diameter which has three seeds fleshy when immature and dark brown when ripe. Seeds: The seeds are brown in colour, 4-9 mm long.

It was observed that $J$. maheswarii showed some unusual interesting character. The plants that were collected during the study in Tiruchendur district showed the presence of lobed leaf. The other morphological characters did not show any variations except the lobed leaf character. The leaf lamina diverged into three lobes from approximately $6-7 \mathrm{~cm}$ at the center of the leaf.

Perusal of the literature also confirmed the leaf character to be simple and entire (Fig. 1A). The leaves were even compared with that of the mango leaves. But the observation of the specimen clearly showed the presence of trilobed leaves which was not reported in earlier studies (Fig. 1B). The leaf arrangement, texture, petiole length, leaf length was same as that of the normal leaves. This can be taken as an example of influence of environmental factors on plant growth. They show some adaptations like variations in leaf character of $J$. maheswarii to survive in the microclimate of that region. Presence of plants with normal leaves in the same 
habitat proves that variations were not necessary for survival. Since the plant is endemic, this variation can be taken as a result of its sensitiveness to the environmental characters like soil, water, exposure to sunlight and humidity (Arteaga et al. 2015).
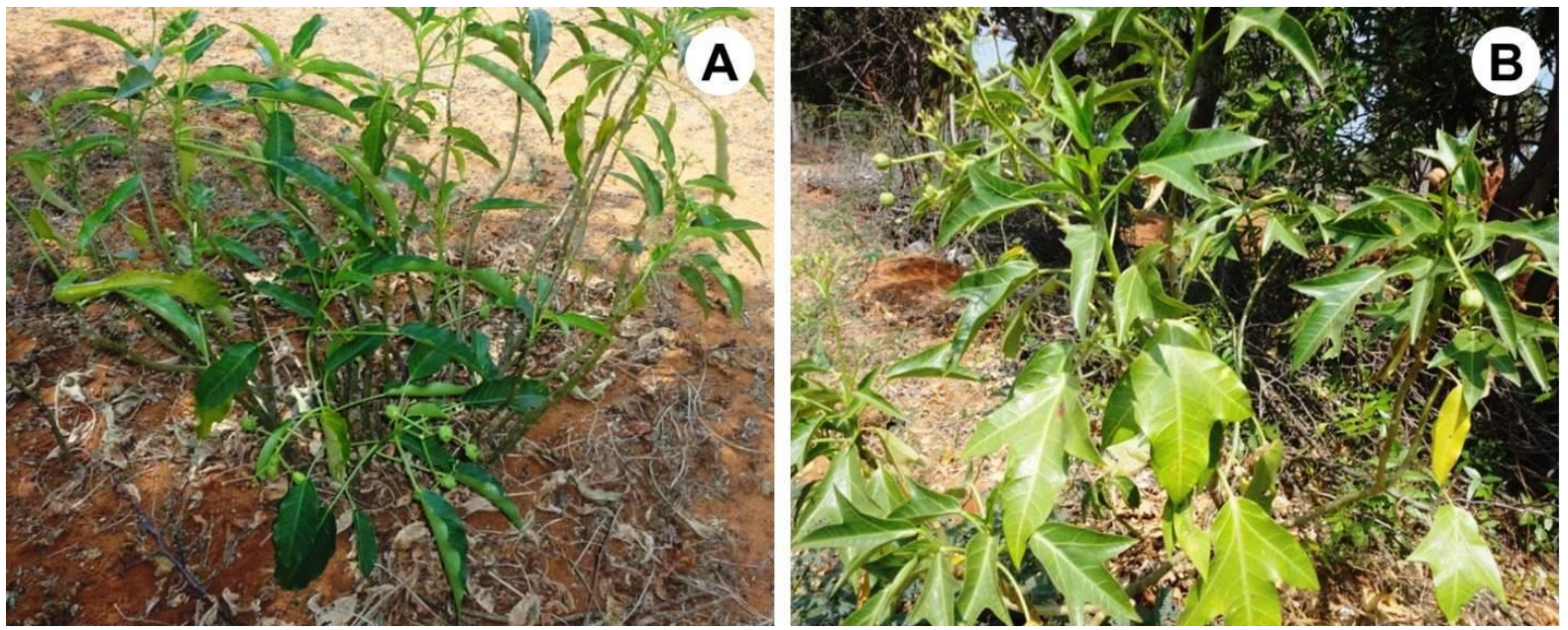

Figure 1. Variations in Jatropha maheswarii Subr. \& Nayar leaves: A, Normal leaves; B, Unusual lobed leaves.

\section{CONCLUSION}

The future comparative studies and intensive research on phenotypical and genotypical characters of both the normal and lobed leaves will determine the genus of the plants with the lobed leaves. Pharmacological work will bring out the medicinal property of this less explored and underutilized taxa.

\section{ACKNOWLEDGMENTS}

I wish to thank the University Grants Commission, SERO, Hyderabad for the financial assistance through Minor Research Project and also thanks to the principal of our college for providing the facilities to carry out my research work.

\section{REFERENCES}

AbdulKader S (2014) Taxonomical Studies on Jatropha maheshwarii Subram. \& Nayar (Euphorbiaceae) - A medicinal under shrub endemic to south Tamil Nadu. Journal of Economic and Taxonomic Botany 38(2): 335-339.

Ahmedullah M \& Nayar MP (1986) Endemic plants of the Indian region. Controller Publication. Botanical Survey of India, Calcutta, India, pp. 176-177.

Arteaga MC, Bello-Bedoy R, Luz JLLDA, Delgadillo J \& Dominguez YR (2015) Phenotypic variation of flowering and vegetative morphological traits along the distribution for the endemic species Yucca capensis (Agavaceae). Botanical Sciences 93(4): 765-770.

Ben CP \& Sivanadanam V (2015) Antimicrobial Efficacy Studies on Rhizome and Fruit pulp Extracts of a Steno Endemic species - Jatropha maheshwarii Subr. \& Nayar. International Journal of Pharma Sciences and Research 6(3): 469-473.

Ben CP, Sivanadanam V \& Gnanasekaran G (2014) Comparative phytochemical screening and antimicrobial efficacy studies on two endemic species - Jatropha maheshwarii Subr. \& Nayar and Jatropha villosa Wight. Journal of Pharmacognosy and Phytochemistry 3(4): 213-219.

Krishnan P \& Paramathma M (2009) Potentials and Jatropha species wealth of India. Current Science 97: 1000-1004.

Sumathi B \& Uthayakumari F (2014) GC MS Analysis of Leaves of Jatropha maheswarii Subr \& Nayar. Science Research Reporter 4(1): 24-30.

Uthayakumari F \& Sumathi B (2011) Pharmacognostical studies on the endemic medicinal plant - Jatropha maheswarii Subr. \& Nayar (Euphorbiaceae). International Journal of PharmTech Research 3(4): 21692174.

Viswanathan MB, Ramesh N, Ahilan A \& Lakshmanaperumalsamy P (2004) Phytochemical constituents and antimicrobial activity from the stems of Jatropha maheswarii. Medicinal Chemistry Research 13(6-7): 36136. 